\title{
Levels of Metals in Kidney, Liver, and Muscle Tissue and their Influence on the Fitness for the Consumption of Wild Boar from Western Slovakia
}

\author{
Jozef Gašparík $^{1}$ • Lukasz J. Binkowski ${ }^{2}$ (i) • Andrej Jahnátek ${ }^{3}$ - Peter Šmehýl ${ }^{1}$. \\ Milan Dobiaš $^{1}$ - Norbert Lukáć ${ }^{4} \cdot$ Martyna Blaszczyk $^{2}$ - Magdalena Semla ${ }^{2}$. \\ Peter Massanyi $^{2}$
}

Received: 8 August 2016 / Accepted: 20 October 2016/Published online: 3 November 2016

(C) The Author(s) 2016. This article is published with open access at Springerlink.com

\begin{abstract}
Due to environmental pollution, wild animals are exposed to various pollutants. Some game animals, such as wild boars are used by people for food, but their meat is not evaluated regarding pollution transfer, since they are unavailable on the official market. The aim of this paper is to present the concentrations of chosen metals $(\mathrm{Cd}, \mathrm{Co}, \mathrm{Cu}, \mathrm{Hg}, \mathrm{Pb}$, and $\mathrm{Zn})$ in the kidneys, liver, and muscles of wild boars $(n=40)$ hunted in eastern Slovakia, as derivatives of physiological distribution and anthropogenic pollution. We found that sex was not a statistically significant factor for metal concentrations. Tissue differences were observed for all the metals studied except for $\mathrm{Co} . \mathrm{Cd}, \mathrm{Cu}$, and $\mathrm{Hg}$ showed the highest median concentrations in kidney tissue with the lowest in muscle tissue $(2.73,3.78$, and $0.061 \mu \mathrm{g} / \mathrm{g}$ w.w., respectively). The highest $\mathrm{Zn}$ median concentration was noted in the liver tissue
\end{abstract}

Łukasz J. Binkowski

ljbinkowski@gmail.com

Jozef Gašparík

jozef.gasparik@uniag.sk

Andrej Jahnátek

jahnatek.andrej@jess.sk

Peter Šmehýl

peter.smehyl@uniag.sk

Milan Dobiaš

milan.dobias@uniag.sk

Norbert Lukáč

norbert.lukac@uniag.sk

Martyna Błaszczyk

martynablaszczyk88@o2.pl with the lowest in muscle tissue. $\mathrm{Co}$ and $\mathrm{Cu}$ concentrations varied according to the age groups. Correlations between metal concentrations in muscle and kidney tissue were not especially strong; such relationships were not found in liver tissue. Among all the potential relationships of the given metal concentrations between tissues, the only significant relationship, albeit weak, was noted for $\mathrm{Pb}$ in muscle and liver tissue. The concentrations found seem not to be extremely high, but according to EU maximum permitted residue levels for $\mathrm{Cd}$ and $\mathrm{Pb}$ concentrations in meat, none of the samples studied was fully fit for human consumption. TWI and risk was also excessive for both metals.

Keywords Game $\cdot$ Pollution $\cdot$ Cadmium $\cdot$ Lead $\cdot$ Mercury

magdalena.semla@o2.pl

Peter Massanyi

peter.massanyi@uniag.sk

1 Department of Poultry Science and Small Animal Husbandry, Slovak University of Agriculture, Trieda Hlinku 2, 94901 Nitra, Slovakia

2 Institute of Biology, Pedagogical University of Cracow, Podbrzezie 3, 31-054 Krakow, Poland

3 Department of Economics, Slovak University of Agriculture, Trieda Hlinku 2, 94901 Nitra, Slovakia

4 Department of Animal Physiology, Slovak University of Agriculture, Trieda Hlinku 2, 94901 Nitra, Slovakia 


\section{Introduction}

Many communities in many parts of the world use the wild animals as a major ingredient in their diet [1,2]. Such animals are believed to be a source of natural meat of the highest quality. Apart from the issues of excellent growing conditions, free, as it were, from farming and medical treatment, they feed in the environment and their food is free from additives such as drugs, antibiotics, and hormones in the form of supplements $[3,4]$. However, the increasing damage to the environment exposes these animals to numerous pollutants, such as metals, pesticides, PCBs and others [5-9]. Exposure is influenced not only by general pollution, but also by the animals' position in the trophic net, their behavior, and their type of habitat [10].

One animal which is crucial in this way in Europe and Asia is the wild boar. The wild boar is a wide-spread and abundant omnivore [11-13]. It has an excellent ability to adapt to anthropogenically changed environments and, as well as the countryside, inhabits suburbs and towns $[14,15]$. Due to this, wild boars' contact with various sources of a variety of pollutants is significant. In many countries, the recent increase in wild boar populations has given rise to an intensification of hunting (also imposed by agriculture), which the consumption of boar meat has also increased $[16,17]$.

Metals, such as cadmium, mercury, lead, and zinc are inextricably linked to anthropogenic activity [18]. Threshold concentrations of some of these metals are regulated in meat and livestock products [19]. Metal concentrations were also measured in the tissue of some wild animals, including wild boars from various parts of the world [20-22]. Due to the fact that exposure is influenced locally, however, no average values can be given for larger areas. Since most part of the wild boar meat is not acquired via the official market, no constant monitoring of levels of potential pollutions in the meat is being carried out, including eastern Slovakia. There is thus an urgent need to present the concentrations obtained in various areas in order to verify the risk of potential consumers. Such data may additionally be used in biomonitoring evaluation of the collection areas [22-24].

The main aim of this paper is to investigate the concentrations of selected metals some of which reflect the industrial impact on the ecosystem (cadmium (Cd), cobalt (Co), copper $(\mathrm{Cu})$, mercury $(\mathrm{Hg})$, lead $(\mathrm{Pb})$, and zinc $(\mathrm{Zn}))$ in the kidney, liver, and muscle tissue of wild-boars collected in southwestern Slovakia. The concentrations were evaluated regarding the potential differences due to sex, tissue, and age group. The relationships between metal concentrations in a given tissue type, as well as comparisons between tissue types, were also checked. Finally, the fitness of the organ and muscle tissues studied was evaluated according to available thresholds, and the condition of the environment was discussed.

\section{Materials and Methods}

Wild boars (20 females, 20 males) were collected by hunters in November and December of 2009 and 2010 in the region of Nitra and Topolcianky in western Slovakia (Fig. 1). Apart from sex, the animals were categorized according to age: 1 , $2,3,4$, and 5 years (each category with four specimens). Samples of kidney, liver, and muscle (musculus semimembranosus) tissue were taken, put in plastic bags, and stored at $-18{ }^{\circ} \mathrm{C}$. One to two grams wet weight (w.w.) of each sample was weighed (Mettler AE 200; accuracy to $0.0001 \mathrm{~g})$ and mineralized in nitric acid $(65 \%$, SupraPUR, Merck, Darmstadt, Germany) in a microwave digestion system (Mars X) in $180^{\circ} \mathrm{C}$ for $15 \mathrm{~min}$ and $70^{\circ} \mathrm{C}$ for 20 a further minutes. The mineralized solutions were filtered (Munktell \& Filtrak, no. 389, Barenstein, Germany) and made up to 50-mL flask with deionized water (Simplicity 185 Millipore SAS, Molsheim, France).

Analysis for $\mathrm{Cd}, \mathrm{Co}, \mathrm{Cu}, \mathrm{Pb}$, and $\mathrm{Zn}$ were carried out with Varian instruments: a flame atomic absorption spectrometer (SpectrAA 240 FS: Co, Cu, Zn) and an electrothermal absorption spectrometer (SpectrAA240Z: Cd and $\mathrm{Pb}$ ). Hg concentrations were measured in fresh samples without the preparation mentioned above with a CVAAS mercury analyzer AMA-254 (Altec, Prague, Czech Republic). The final results, after comparing them to the limits of detection (Table 1), were expressed as microgram per gram w.w.

For calibration and quality checks, including control solutions and spikes, a multi-standard solution CertiPUR (Merck, Darmstadt, Germany) was used. All the recoveries were satisfactory (between 90 and 110\%). The BCR-185R certified reference material (CRM) was also analyzed as the final check of the whole protocol $(N=11)$ (Table 1).

\section{Statistical Analysis}

Since the data did not meet the demands of parametric tests, we carried out the main factor robust ANOVA on ranks [25]. Age, sex, and tissue type were used as categorical factors. We used $R$ Spearman correlation factors to evaluate the potential relationships between metals in the given tissues, as well as the relationships between tissues regarding the given metal. The significance level was set at 0.050 . All the calculations and analyses were done with Excel 2016 for Mac (Microsoft) and Statistica 12 (StatSoft).

\section{Results}

In all the samples, all the metals studied were present at levels above their detection limits. Since the influence of sex was not significant for all the metals studied (the lowest $p$ noted for $\mathrm{Cd}$ was 0.060 ), the data was pooled regardless of sex. 
Table 1 Analytical parameters of methods used with the results of CRM analysis $(N=11)$

\begin{tabular}{lllll}
\hline Element & $\begin{array}{l}\text { Limit of detection } \\
\text { (in solution) }\end{array}$ & $\begin{array}{l}\text { Limit of detection } \\
\text { (in fresh sample) }\end{array}$ & Method & $\begin{array}{l}\text { CRM } \\
\text { (with RSD) }\end{array}$ \\
\hline $\mathrm{Cd}$ & $10 \mathrm{ng} / \mathrm{L}$ & $0.5 \mathrm{ng} / \mathrm{g}$ & ET-AAS & $+8.1 \%(7.7 \%$ \\
$\mathrm{Co}$ & $5.0 \mu \mathrm{g} / \mathrm{L}$ & $0.25 \mu \mathrm{g} / \mathrm{g}$ & F-AAS & - \\
$\mathrm{Cu}$ & $2.0 \mu \mathrm{g} / \mathrm{L}$ & $0.1 \mu \mathrm{g} / \mathrm{g}$ & F-AAS & $-1.6 \%(4.1 \%)$ \\
$\mathrm{Hg}$ & - & $0.075 \mathrm{ng} / \mathrm{g}$ & CV-AAS & $-4.7 \%(3.9 \%)$ \\
$\mathrm{Pb}$ & $10 \mathrm{ng} / \mathrm{L}$ & $0.5 \mathrm{ng} / \mathrm{g}$ & ET-AAS & $+4.3 \%(8.1 \%)$ \\
$\mathrm{Zn}$ & $0.6 \mu \mathrm{g} / \mathrm{L}$ & $0.03 \mu \mathrm{g} / \mathrm{g}$ & F-AAS & $-0.2 \%(6.1 \%)$ \\
\hline
\end{tabular}

${ }^{\text {a }}$ For Hg BCR-463 CRM was used, for other elements BCR-185R, no appropriate CRM for Co was found
The general scheme of the increasing concentrations, with some deviations between tissues, was as follows: $\mathrm{Hg}<\mathrm{Pb}<\mathrm{Co}<\mathrm{Cd}<\mathrm{Cu}<\mathrm{Zn}$. The tissue factor was statistically significant for $\mathrm{Cd}, \mathrm{Cu}, \mathrm{Pb}, \mathrm{Hg}$, and $\mathrm{Zn}$ (for all the metals $p<0.001)$ and non-significant for the concentrations of Co $(p=0.272)$. With regard to this factor, each tissue differed from others with the exception of muscle and kidney tissue for $\mathrm{Pb}$, and liver and kidney tissue for $\mathrm{Hg}$. $\mathrm{Cd}, \mathrm{Cu}$, and $\mathrm{Hg}$ had the highest median concentrations in kidney tissue $(2.73,3.78$ and $0.061 \mu \mathrm{g} / \mathrm{g}$ w.w., respectively; Table 2$)$; levels of concentrations in liver tissue $(0.474,3.31$ and $0.031 \mu \mathrm{g} / \mathrm{g}$ w.w., respectively) were lower, and the lowest average concentrations of these metals were noted in muscle tissues $(0.155,1.62$ and $0.011 \mu \mathrm{g} / \mathrm{g}$ w.w., respectively; Figs. 2,3 and 4). The highest $\mathrm{Zn}$ concentrations were noted in liver tissue (26.0 $\mu \mathrm{g} / \mathrm{g}$ w.w.), the lowest in muscle tissue $(12.1 \mu \mathrm{g} /$ g w.w.; Fig. 5). Pb occurred in the highest average concentration in muscle tissue $(0.441 \mu \mathrm{g} / \mathrm{g}$ w.w.; Table 2$)$, the lowest in liver tissue (0.188 $\mu \mathrm{g} / \mathrm{g}$ w.w.; Fig. 2).

Concentrations of $\mathrm{Co}(p=0.008)$ and $\mathrm{Cu}(p<0.001)$ varied between the age groups studied. Generally, the highest concentrations were observed in animals of 2 and 3 years old (Fig. 3, 4). For both metals, the statistically significant differences occurred between 2-year-old animals (Co $0.495 \mu \mathrm{g} / \mathrm{g}$ w.w., $\mathrm{Cu} 3.50 \mu \mathrm{g} / \mathrm{g}$ w.w.), 4-year-olds (Co $0.379 \mu \mathrm{g} / \mathrm{g}$ w.w., $\mathrm{Cu} 2.74 \mu \mathrm{g} / \mathrm{g} \mathrm{w} . w$.$) , and 5-year-olds (Co 0.390 \mu \mathrm{g} / \mathrm{g}$ w.w., $\mathrm{Cu}$ $2.95 \mu \mathrm{g} / \mathrm{g}$ w.w.). In the case of $\mathrm{Cu}$, the additional significant differences were noted between 3-year-old animals, four-yearolds, and five-year-olds. In all the cases mentioned, the lowest concentrations were observed in older animals.

\section{Correlations}

We observed no relationship between metals in liver tissue. Correlations in muscle and kidney tissue were rather weak, but in three cases higher than 0.500 (Table 3).

In the case of relationships of the given metal concentrations between tissues, the only significant relationship was noted for $\mathrm{Pb}$ in muscle and liver tissue ( $R$ Spearman 0.448). The generally known relationship of cadmium concentrations in liver and kidney tissue was not observed in the study $(R$ Spearman 0.110).

\section{Discussion}

We found that the sex factor had no influence on the levels of the metals studied, but the concentrations were differentiated by tissue $(\mathrm{Cd}, \mathrm{Cu}, \mathrm{Pb}, \mathrm{Zn}, \mathrm{Hg})$ and age group $(\mathrm{Co}$ and $\mathrm{Cu})$. No unanimous scheme of accumulation for metals and for tissue type was observed. Correlations found were not strong and not numerous.
Fig. 1 The site (gray ellipse) of the research - the Nitra and Topolcianky region in south western Slovakia (Europe)

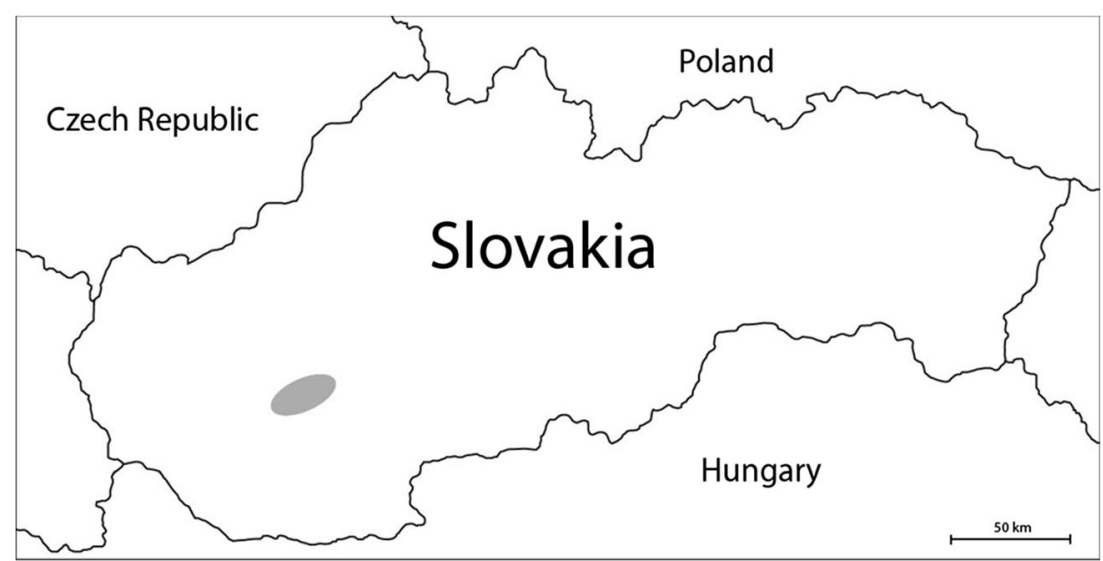


Table 2 Concentrations of metals studied ( $\mu \mathrm{g} / \mathrm{g}$ w.w.) in the division to tissue type $(N=40)$

\begin{tabular}{llccccccl}
\hline Tissue & Metal & Median & Minimum & Maximum & $\mathrm{Q}_{1}$ & $\mathrm{Q}_{3}$ & Range & IQR \\
\hline Muscle & $\mathrm{Cd}$ & 0.155 & 0.043 & 0.373 & 0.089 & 0.220 & 0.331 & 0.131 \\
Muscle & $\mathrm{Cu}$ & 1.62 & 0.935 & 2.51 & 1.38 & 1.79 & 1.57 & 0.41 \\
Muscle & $\mathrm{Hg}$ & 0.011 & 0.000 & 0.251 & 0.006 & 0.026 & 0.251 & 0.020 \\
Muscle & $\mathrm{Pb}$ & 0.441 & 0.039 & 61.3 & 0.274 & 0.645 & 61.3 & 0.371 \\
Muscle & $\mathrm{Zn}$ & 12.1 & 8.46 & 23.1 & 10.3 & 16.0 & 14.6 & 5.7 \\
Liver & $\mathrm{Cd}$ & 0.474 & 0.190 & 1.92 & 0.365 & 0.635 & 1.73 & 0.270 \\
Liver & $\mathrm{Cu}$ & 3.31 & 2.10 & 5.86 & 3.03 & 3.52 & 3.77 & 0.50 \\
Liver & $\mathrm{Hg}$ & 0.032 & 0.003 & 0.113 & 0.026 & 0.055 & 0.111 & 0.029 \\
Liver & $\mathrm{Pb}$ & 0.188 & 0.040 & 1.29 & 0.116 & 0.305 & 1.25 & 0.189 \\
Liver & $\mathrm{Zn}$ & 26.0 & 19.9 & 52.7 & 23.6 & 29.4 & 32.8 & 5.9 \\
Kidneys & $\mathrm{Cd}$ & 2.73 & 0.36 & 8.82 & 2.14 & 4.06 & 8.45 & 1.92 \\
Kidneys & $\mathrm{Cu}$ & 3.78 & 2.09 & 7.19 & 3.20 & 4.15 & 5.10 & 0.96 \\
Kidneys & $\mathrm{Hg}$ & 0.061 & 0.001 & 0.739 & 0.026 & 0.114 & 0.738 & 0.088 \\
Kidneys & $\mathrm{Pb}$ & 0.345 & 0.049 & 1.10 & 0.169 & 0.526 & 1.05 & 0.357 \\
Kidneys & $\mathrm{Zn}$ & 19.9 & 15.8 & 31.9 & 18.2 & 23.2 & 16.1 & 5.0 \\
All & $\mathrm{Co}$ & 0.438 & 0.131 & 1.14 & 0.330 & 0.558 & 1.01 & 0.228 \\
\hline
\end{tabular}

$Q$ quartiles, $I Q R$ interquartile range

${ }^{a}$ Since Co concentrations did not differ between tissues, they are presented without the division

\section{Metal Concentrations}

Generally, wild animals show a higher accumulation of pollutants and variation of these in their tissues than farm animals. They may be efficient biomonitors of the current pollution of the ecosystem [26]. The accumulation may be influenced by many factors. Many investigations have revealed no connection between the accumulation and the sex of the

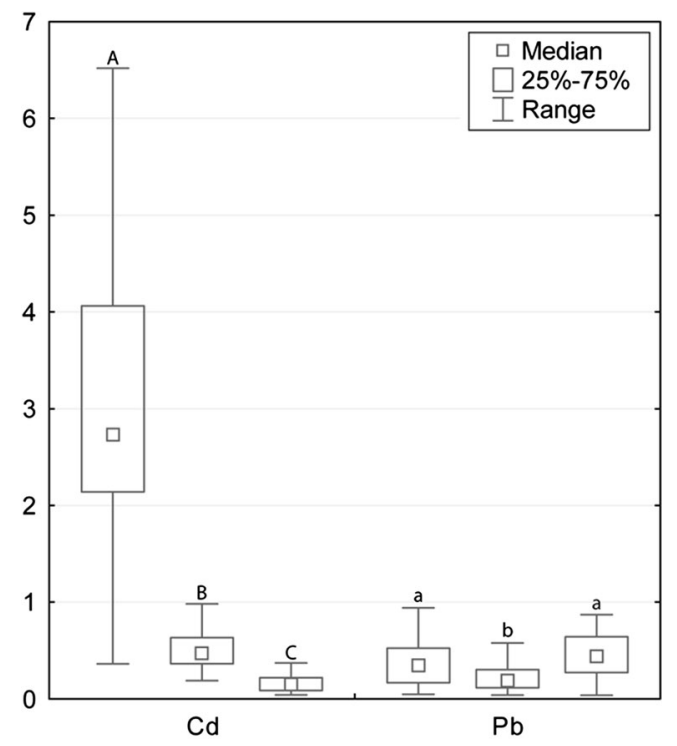

Fig. $2 \mathrm{Cd}, \mathrm{Cu}$, and $\mathrm{Pb}$ concentrations ( $\mu \mathrm{g} / \mathrm{g}$ w.w.) in the kidney, liver, and muscle tissue (consecutively) of wild boars studied. Since the factors of sex and age were not significant, the groups were merged. Different letters indicate statistically significant differences in concentrations between tissue types. Range presented for non-outlier observations animals (e.g., Binkowski et al. 2016), a conclusion borne out in our study, so some researchers have decided to go as far as to omit this factor in the sampling protocol or inference [27-29]. The size of accumulation usually differs between metals. In the case of animals studied, the highest $\mathrm{Cd}, \mathrm{Cu}$, and $\mathrm{Hg}$ concentrations were observed in kidney tissue. The highest accumulation of metals in kidney tissue was also

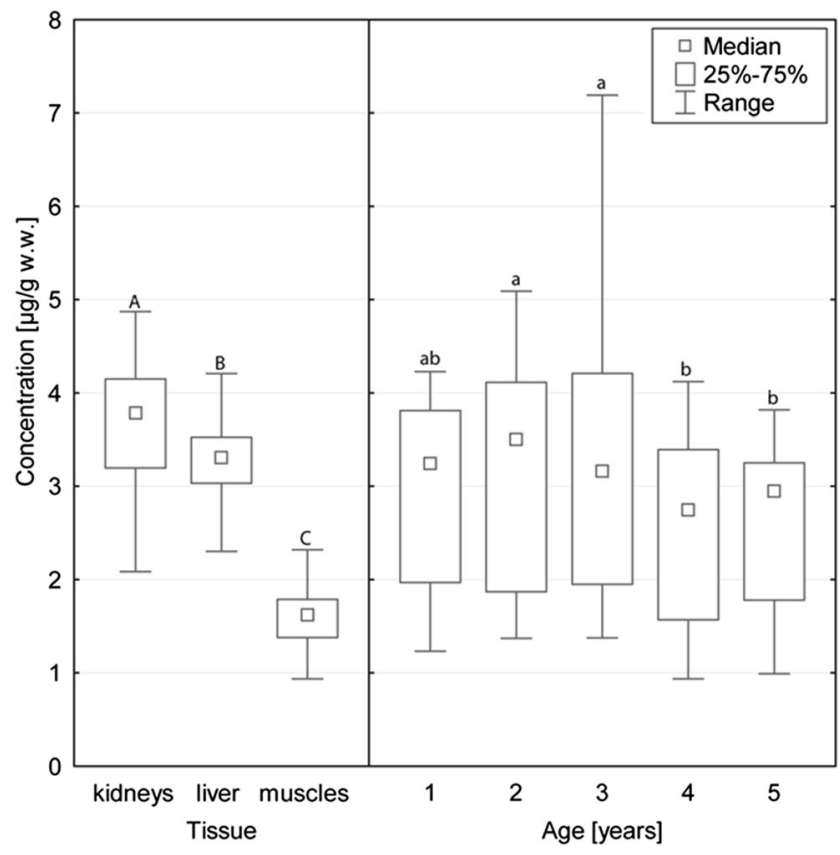

Fig. $3 \mathrm{Cu}$ concentrations in animals studied, with the significant division into tissue types and age groups studied. Different letters indicate statistically significant differences in concentrations between tissue types and age groups. Range presented for non-outlier observations 
observed in wild boars from Croatia [26, 30] and northern Poland [31].

$\mathrm{Cd}$ concentrations found in our study were medium in comparison to the literature, and higher concentrations had already been observed [30]. We may therefore state that cadmium exposure (generally low) in the habitat was comparable to other areas. On the other hand, when compared to data gathered in Austria, values in the muscle tissue of wild boars hunted in Slovakia were significantly higher [32]. The significantly higher concentrations found in kidney and liver tissue than in muscle tissue are probably connected with the known turnover of $\mathrm{Cd}$ in the body where more than $75 \%$ of the total burden is deposited in these two organs $[18,33]$. We initially suspected that we would observe significantly higher Cd concentrations in older animals, since in many studies, age-related $\mathrm{Cd}$ accumulation has been noted [18, 27, 34, 35]. No such trend was encountered in the animals studied, but in particular, the highest $\mathrm{Cd}$ concentrations were observed in the oldest animals (similarly to [27]).

We found higher $\mathrm{Pb}$ accumulation in muscle tissue than in kidney tissue, which was also mentioned in the literature [26]. Non-outlier maximum and upper quartile concentrations noted in all the organs studied did not exceed $1.0 \mu \mathrm{g} / \mathrm{g}$ w.w., which is not a high value in comparison to other species and areas $[27,36]$. This suggests that, in most specimens, pollution did not result from the lead bullet, but other sources of lead were responsible. Apart from the general pollution of the environment (including air, water, sewage, and landfill waste), exposure through the trophic chain was also possible. One of the potential exposure routes for wild boars may be a transfer by the trophic net from $\mathrm{Pb}$ poisoned waterfowl [36-38] because in some circumstances, poisoned water birds may be easily hunted by boars, since the animal is an omnivore [15]. Based on the relatively low concentrations found, however, the abovementioned problem did not occur in the specimens studied.

Despite some findings from bird studies, $\mathrm{Hg}$ concentrations in the body usually reach the highest values in kidney tissue [27, 31, 39]. Our results confirm this finding with the additional observation that concentrations in kidney and liver tissue are comparable. In general, the contamination of wild animals with $\mathrm{Hg}$ in Slovakia is believed to be decreasing [40]. In comparison to $\mathrm{Hg}$ concentrations in the liver and kidney tissue of wild boars from northern Poland, the values obtained in the study are slightly lower in kidney tissue, but comparable in liver tissue [31]. Accumulation in muscle tissue was also slightly lower [27]. In comparison to concentrations observed in wild boars shot in the air-polluted Zemplin area (eastern Slovakia), values noted in our studies were significantly lower, for kidney and liver tissue up to seven or eight times lower. Concentrations in muscle tissue were, however, similar [21]. However, concentrations found in the muscle tissue in wild boars from Slovakia were slightly higher than those found in Austria [32]. As our and other research showed, $\mathrm{Hg}$ accumulation is not linked with the age of an animal [20].

The other elements studied, $\mathrm{Co}, \mathrm{Cu}, \mathrm{Co}$, and $\mathrm{Zn}$, belong to the group of essential elements [18]. They are less intensively studied in the literature as xenobiotic metals. The highest median concentrations were noted for $\mathrm{Zn}$, which is consistent with the literature. Similar concentrations in kidney tissue ( $21.5 \mu \mathrm{g} / \mathrm{g}$ w.w., recalculated from $91.3 \mu \mathrm{g} / \mathrm{g}$ d.w. according to the protocol [41]) were noted in wild boars from southern Poland shot in the late 1980-1989. The concentrations we found in muscle tissue, however, were two times lower (12.1 compared to $30.5 \mu \mathrm{g} / \mathrm{g}$ w.w.) [42]. Studies on red deer revealed that muscle tissue from that species were richer in $\mathrm{Zn}$ than liver and kidney tissue was, which is not consistent with our observations [43]. Co and $\mathrm{Cu}$ were the only metals studied whose concentrations revealed differences according to age group. The comparison to literature is hard, since similar data is scarce. The categorization of hunted game according to age is problematic because most hunted animals are young [27]. Our observations suggest that accumulation of these metals may be inversely proportional to age. $\mathrm{Cu}$ concentrations in the kidney and liver tissue of animals studied were slightly lower in comparison to animals from the north of Poland [27]. Co concentrations revealed no variation between tissues, in contrast to the values noted in red deer from northern Poland. Concentrations in wild boars were also higher [43]. This may be explained by the different position these two species assume in the trophic chain.

Only a few moderately strong correlations were found. The strongest, $\mathrm{Cu}-\mathrm{Zn}$ in muscle tissue, occurred twice and may be explained by the numerous physiological functions of both elements, including being cofactors of many enzymes [18, 43]. We initially suspected positive correlations of xenobiotic metals, which might suggest the source of both elements in the habitat (e.g., industry) [44]. We observed, however, no such relationship, probably because the concentrations found were generally insufficiently high to lead to intense exposure.

\section{Fitness for Consumption}

Due to the increasing population of wild boar, its meat is widely consumed by people around the world. Both the supply and the quality of the meat (including the flavor, fatty composition, and higher $\alpha$-tocopherol concentrations) have stimulated the growing demand of the market [45]. Apart from many xenobiotics, metal concentrations in meat and edible organs are also considered regarding its fitness for consumption [19]. Official documents in Europe, however, include no thresholds for game meat and focus mainly on farm-reared animals, with the exception of fish. This is probably the upshot of the historic situation, when game meat was consumed locally only by small numbers of people [46]. 


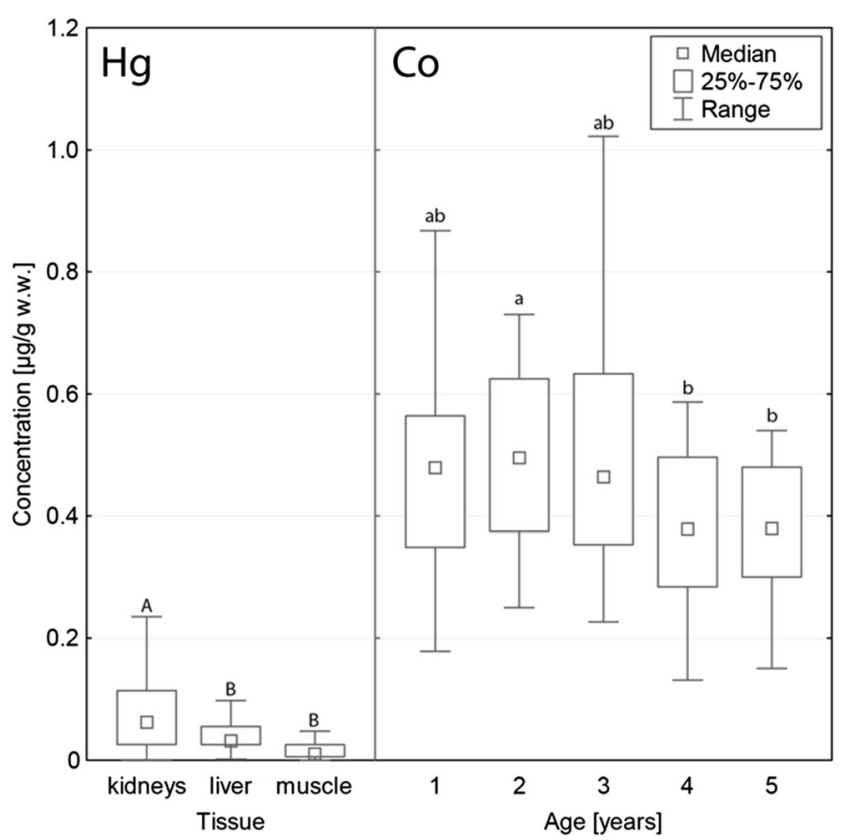

Fig. $4 \mathrm{Hg}$ and Co concentrations in animals studied. $\mathrm{Hg}$ concentrations differed between tissue types, but Co differed only between age groups. Different letters indicate statistically significant differences in concentrations between tissue types and age groups. Range presented for non-outlier observations

Comparing the values obtained with the threshold dedicated to pig meat, we may evaluate only two metals, $\mathrm{Cd}$ and $\mathrm{Pb}$ (Hg concentrations are regulated only in fish and fishery

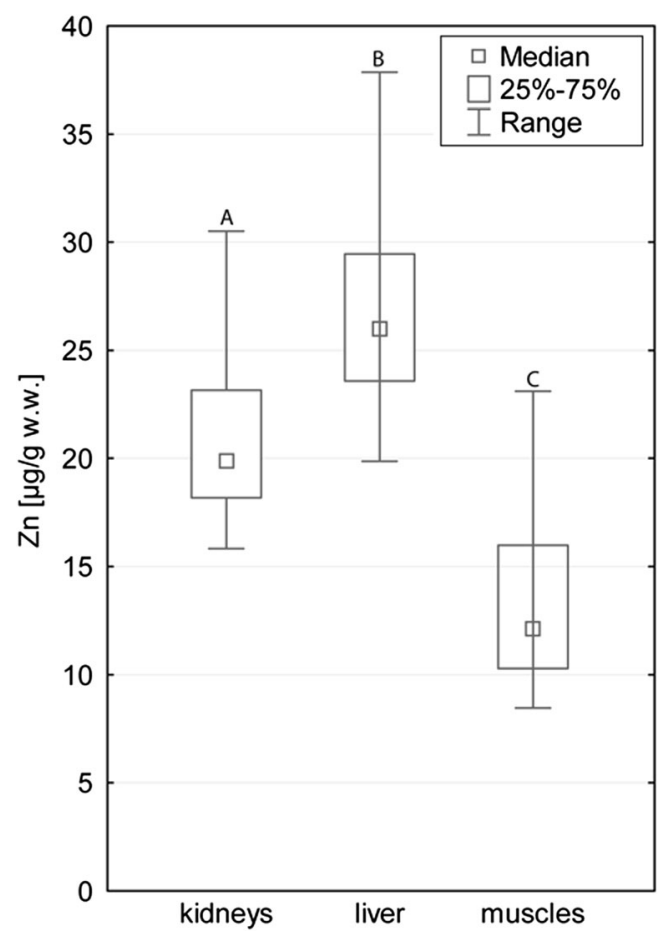

Fig. $5 \mathrm{Zn}$ concentrations in different tissue types studied of wild boar. Different letters indicate statistically significant differences in concentrations between tissue types studied. Range presented for nonoutlier observations
Table $3 R$ Spearman correlation factors (higher than 0.5 or lower than -0.5 ) noted between metals in tissue studied

\begin{tabular}{lcc}
\hline Tissue & Metals & $R$ Spearman \\
\hline Muscles & $\mathrm{Cu}-\mathrm{Zn}$ & 0.618 \\
Kidneys & $\mathrm{Cd}-\mathrm{Pb}$ & -0.564 \\
& $\mathrm{Cu}-\mathrm{Zn}$ & 0.514 \\
\hline
\end{tabular}

products). The Cd threshold varies between meat, liver, and kidney tissue and are as follows: $0.05,0.5$, and $1.0 \mu \mathrm{g} / \mathrm{g} \mathrm{w} . \mathrm{w}$. [19]. The minimal concentration found in muscle tissue of wild boars examined was only a little lower than the threshold $(0.043 \mu \mathrm{g} / \mathrm{g}$ w.w. $)$, but the lower quartile was already higher $(0.089 \mu \mathrm{g} / \mathrm{g}$ w.w. $)$, which means that meat from more than $75 \%$ specimens studied exceeded the permissible Cd concentrations. The exceedances are less numerous in liver tissue, but still almost half of the specimens had higher concentrations than the threshold. In the case of kidney tissue, only one specimen fell within the permissible range, so the kidney tissue of $98 \%$ of the specimens studied were unfit for human consumption. The only possible explanation for the exceedances is the environmental exposure of the animals [46].

The $\mathrm{Pb}$ threshold varies only for meat $(0.1 \mu \mathrm{g} / \mathrm{g}$ w.w. $)$ and edible organs $(0.5 \mu \mathrm{g} / \mathrm{g}$ w.w.) [19]. The thresholds were exceeded in the muscle tissue of $90 \%$ of specimens, in the kidney tissue of $28 \%$ of specimens and in the liver tissue of $10 \%$ of specimens. Here, as well as environmental pollution ammunition also plays a role. The common problem of $\mathrm{Pb}$ concentrations in game meat is linked with $\mathrm{Pb}$ shots and bullet fragments. Such $\mathrm{Pb}$ transfer depends on the type of bullet, its mushrooming abilities, the size of the animals, and the tissue hit. Tissue $25-30 \mathrm{~cm}$ or even further away from the wound may still contain small $\mathrm{Pb}$ particles [47, 48]. Other research showed that the $\mathrm{Pb}$ transfer is more efficient in cases in which lead pellet ammunition (the ammunition more commonly used in hunting small game, such as waterfowl, hares, and foxes) was used rather than bullets (the ammunition more commonly used in hunting big game). The problem of lead transfer cannot be solved without banning the use of $\mathrm{Pb}$ bullets, but the resistance of the hunting community is considerable. Hunters commonly think that the lead-free ammunition is inefficient from a ballistic point of view (e.g., they are prone to injuring animals rather than killing them). This is still questionable, but scientific research shows that the efficiency is not dependent on whether the ammunition is lead or lead-free, but rather the type of bullet $[49,50]$.

Despite the established permissible content in food and provisional tolerable weekly intake (PTWI), some organizations postulate that all $\mathrm{Pb}$ should be eradicated because of its high toxicity according to the ALARA approach (As Low As Reasonably Achievable) [19, 51, 52]. Pb PTWI is especially believed to be no longer appropriate and should be lowered. Thus, we assessed the risk to consumers of $\mathrm{Pb}$ from wild boar meat on the basis of the new protocol proposed by European 
Table 4 Estimated MOEs for different endpoints by the intensity of game consumption

\begin{tabular}{llll}
\hline Concentration used $[\mu \mathrm{g} / \mathrm{g}$ w.w. & MOE-normal consumption & MOE-high consumption & MOE-extreme consumption \\
\hline Cardiovascular effects & & & $0.9-2.1$ \\
$\quad$ Muscle ( $\mathrm{Q}_{2}$ 0.1550) & $1.2-4.1$ & $1.2-3.7$ & 0.03 \\
$\quad$ Muscle (Max. 0.3732) & $0.6-1.0$ & 0.2 & $0.4-0.9$ \\
Nephrotoxicity & & & $0.5-1.6$ \\
$\quad$ Muscle (Q 0.1550$)$ & $0.5-1.7$ & 0.1 & 0.01 \\
Muscle (Max. 0.3732) & $0.3-0.4$ & & \\
\hline
\end{tabular}

MOE (margin of exposure) values calculated for normal consumption (2 game meals per year), high consumption (10 game meals per year) and extreme consumption (90 game meals per year) [53]

Food Safety Agency (EFSA) [51]. This attempt is based on the margin of exposure value (MOE) calculated as the ratio between a defined point on the dose-response curve for the adverse effect (the benchmark dose lower confidence limit) and estimated intake with food. According to EFSA's opinion, a MOE value of 10 or greater ensures that there is no appreciable risk of a clinically significant change in the prevalence of chronic kidney disease (CKD) and an increase in systolic blood pressure (SBP). The risk of a MOE of greater than 1.0 is very low [51]. We may say then that the consumption of the wild boar meat studied poses no special risk of SBP to any consumer when we discuss the average concentrations (medians). For samples containing maximum concentrations, the risk is high, especially for high and extreme consumption groups (Table 4). Similar results were obtained for CKD, but here, the risk calculated in every group is higher even for average concentrations found. It should be stressed that MOE values only indicate a level of concern and do not quantify risk [54].

In the case of Cd, the simpler PTWI approach is still common. The exceedances of PTWI calculated on the basis of concentrations found in animals studied are common: only muscle tissue containing average concentrations seems to be safe for human consumption where $\mathrm{Cd}$ is concerned (Table 5).

Concentrations of other metals studied are currently not officially regulated by law or norms [19]. Older documents from various countries, however, present the then permissible values for canned meat products. In Poland, for instance, the threshold in the $1980 \mathrm{~s}$ was 8.0 and $50.0 \mathrm{mg} / \mathrm{kg}$ for $\mathrm{Cu}$ and $\mathrm{Zn}$, respectively [57]. According to them, all the samples from our study fell within the permissible range of $\mathrm{Cu}$ and $\mathrm{Zn}$ concentrations.

\section{Conclusions}

Concentrations found in the study relative to literature data seem not to be increased. During the literature comparison, we observed no significant trends in time, but only rather a moderate variation in concentrations between areas. Some metals in the study, such as $\mathrm{Cd}$ and $\mathrm{Pb}$, however, reached concentrations sufficiently high to exceed the permissible accumulation in meat (thresholds are only established for farm-reared meat) and to increase the risk of the consumers. It should be stressed here that $\mathrm{Cd}$ and $\mathrm{Pb}$ concentrations were not correlated and thus, only one specimen which had safe $\mathrm{Cd}$ concentrations in kidney tissue exceeded concentrations of $\mathrm{Pb}$ in muscle tissue, so none of the animals studied was fully fit for human consumption. This observation imposes questions about the usefulness of the thresholds intended for farm-reared animals for game meat, and also about the necessity of the regular monitoring of selected metallic pollutants in hunted animals.

Table 5 Simulation of the consumer exposure with reference to $\mathrm{Cd}$ concentrations found in the tissue studied according to the provisional tolerable weekly intake (PTWI) calculated for $70 \mathrm{~kg}$ person: $175 \mu \mathrm{g}$

\begin{tabular}{|c|c|c|c|c|}
\hline $\begin{array}{l}\text { Concentration used }(\mu \mathrm{g} / \mathrm{g} \\
\text { w.w.) }\end{array}$ & $\begin{array}{l}\text { Weight of the total portion ( } 100 \% \\
\text { PTWI) }\end{array}$ & $\begin{array}{l}\text { No. of } 200 \mathrm{~g} \\
\text { portions }\end{array}$ & $\begin{array}{l}\text { Contribution of } 4 \text { meals to PTWI } \\
(\%)\end{array}$ & $\begin{array}{l}\text { Total weekly } \\
\text { intake } \\
\text { (\% PTWI) }\end{array}$ \\
\hline $\operatorname{Muscle}\left(\mathrm{Q}_{2} 0.155\right)$ & 1129 & 5.6 & 70.9 & $119-211$ \\
\hline Muscle (max. 0.373) & 469 & 2.3 & 171 & $219-311$ \\
\hline Liver $\left(\mathrm{Q}_{2}\right.$ 0.474) & 369 & 1.8 & 217 & $265-357$ \\
\hline Liver (max. 1.92) & 91.1 & 0.5 & 878 & $926-1018$ \\
\hline Kidneys $\left(\mathrm{Q}_{2} 2.73\right)$ & 64.1 & 0.3 & 1249 & $1297-1389$ \\
\hline Kidneys (max. 8.82) & 19.9 & 0.1 & 4030 & $4078-4170$ \\
\hline
\end{tabular}

Simulation calculated for median $\left(\mathrm{Q}_{2}\right)$ and maximum value noted (max.). Initial PTWI value is $2.5 \mu \mathrm{g} / \mathrm{g}$ body weight [55]. Total weekly intake includes 4 meals of product studied, general weekly intake taken from literature 48-140\% [46, 56] 
Acknowledgments The research was funded by projects VEGA 1/0511/15, 1/0760/15, 1/0857/14, APVV-14-0637, APVV-0304-12, APVV-15-0543 and KEGA 006/SPU-4/2015. The paper was written during Łukasz J. Binkowski's research stay at the Slovak University of Agriculture in Nitra, financed by SAIA funds (National Scholarship Programme of the Slovak Republic for the Support of Mobility of Students, PhD Students, University Teachers, Researchers and Artists, project no. 15294).

Open Access This article is distributed under the terms of the Creative Commons Attribution 4.0 International License (http:// creativecommons.org/licenses/by/4.0/), which permits unrestricted use, distribution, and reproduction in any medium, provided you give appropriate credit to the original author(s) and the source, provide a link to the Creative Commons license, and indicate if changes were made.

\section{References}

1. Bjerregaard P, Johansen P, Mulvad G et al (2004) Lead sources in human diet in Greenland. Environ Health Perspect 112:1496-1498. doi:10.1289/ehp.7083

2. Johansen P, Asmund G, Riget F (2004) High human exposure to lead through consumption of birds hunted with lead shot. Environ Pollut 127:125-129. doi:10.1016/S0269-7491(03)00255-0

3. Szmańko T, Górecka J, Korzeniowska M et al (2007) Comparison of chosen quality parameters of meat from wild boar and domestic pigs. Polish J Food Nutr Sci 57:523-528

4. Klein PN (2004) Game meat: a complex food safety and animal health issue. Food Saf Mag 1-6

5. Shore RF, Casulli A, Bologov V et al (2001) Organochlorine pesticide, polychlorinated biphenyl and heavy metal concentrations in wolves (Canis lupus L. 1758) from north-west Russia. Sci Total Environ 280:45-54. doi:10.1016/S0048-9697(01)00802-6

6. Kramárová M, Massányi P, Slamecka J et al (2005) Distribution of cadmium and lead in liver and kidney of some wild animals in Slovakia. J Environ Sci Heal Part A 40:593-600. doi:10.1081 /ESE-200046605

7. Gasparik J, Massanyi P, Slamecka J et al (2004) Concentration of selected metals in liver, kidney, and muscle of the red deer (Cervus elaphus). J Environ Sci Heal Part A 39:2105-2111. doi:10.1081 /ESE-120039378

8. Kolesarova A, Slamecka J, Jurcik R et al (2008) Environmental levels of cadmium, lead and mercury in brown hares and their relation to blood metabolic parameters. J Environ Sci Heal Part A 43:646-650. doi:10.1080/10934520801893741

9. Gasparik J, Vladarova D, Capcarova M et al (2010) Concentration of lead, cadmium, mercury and arsenic in leg skeletal muscles of three species of wild birds. J Environ Sci Heal Part A 45:818-823. doi:10.1080/10934521003708992

10. Abbasi NA, Jaspers VLB, Chaudhry MJ et al (2015) Influence of taxa, trophic level, and location on bioaccumulation of toxic metals in bird's feathers: a preliminary biomonitoring study using multiple bird species from Pakistan. Chemosphere 120:527-537. doi:10.1016/j.chemosphere.2014.08.054

11. Markov NI, Neifel ND, Estafev AA (2004) Ecological aspects of dispersal of the wild boar, Sus scrofa L., 1758, in the northeast of European Russia. Russ J Ecol 35:131-134

12. Sáez-Royuela C, Tellería JL (1986) The increased population of the wild boar (Sus scrofa L.) in Europe. Mamm Rev 16:97-101. doi:10.1111/j.1365-2907.1986.tb00027.x

13. Schley L, Roper TJ (2003) Diet of wild boar Sus scrofa in Western Europe, with particular reference to consumption of agricultural crops. Mamm Rev 44:506-556. doi:10.1046/j.13652907.2003.00010.x

14. Cahill S, Llimona F, Gràcia J (2003) Spacing and nocturnal activity of wild boar Sus scrofa in a Mediterranean metropolitan park. Wildlife Biol 9:3-13

15. Giménez-Anaya A, Herrero J, Rosell C et al (2008) Food habits of wild boars (Sus scrofa) in a mediterranean coastal wetland. Wetlands 28:197-203

16. Geisser H, Reyer HU (2004) Efficacy of hunting, feeding, and fencing to reduce crop damage by wild boars. J Wildl Manag 68: 939-946

17. Baubet E, Bonenfant C, Brandt S (2004) Diet of the wild boar in the French Alps. Galemys 16:101-113

18. Nordberg GF, Fowler BA, Nordberg M, Friberg LT (2007) Handbook on the toxicology of metals. Elsevier, London

19. EC (2006) 1881/2006. Setting maximum levels for certain contaminants in foodstuffs. Off J Eur Communities 364:5-24

20. Srebočan E, Crnić AP, Ekert-Kabalin AM (2011) Cadmium, lead, and mercury concentrations in tissues of roe deer (Capreolus capreolus L.) and wild boar (Sus scrofa L.) from lowland Croatia. Czech J Food Sci 29:624-633

21. Piskorová L, Vasilková Z, Krupicer I (2003) Heavy metal residues in tissues of wild boar (Sus scrofa) and red fox (Vulpes vulpes) in the Central Zemplin region of the Slovak Republic. Czech J Anim Sci 48:134-138

22. Santiago D, Motas-Guzmán M, Reja A et al (1998) Lead and cadmium in red deer and wild boar from Sierra Morena Mountains (Andalusia, Spain). Bull Environ Contam Toxicol 61:730-737. doi:10.1007/s001289900822

23. Suran J, Prisc M, Rasic R et al (2013) Malondialdehyde and heavy metal concentrations in tissues of wild boar (Sus scrofa L.) from central Croatia. J Environ Sci Heal Part B 48:147-152. doi:10.1080 /03601234.2013.727672

24. Yarsan E, Yipel M, Dikmen B et al (2014) Concentrations of essential and non-essential toxic trace elements in wild boar (Sus scrofa L., 1758) tissues from southern Turkey. Bull Environ Contam Toxicol 92:10-14. doi:10.1007/s00128-013-1134-0

25. Quinn GP, Keough MJ (2002) Experimental design and data analysis for biologists. University Press, Cambridge

26. Bilandžić N, Sedak M, Crossed D, Signokić M, Šimić B (2010) Wild boar tissue levels of cadmium, lead and mercury in seven regions of continental Croatia. Bull Environ Contam Toxicol 84: 738-743. doi:10.1007/s00128-010-9999-7

27. Falandysz J (1994) Some toxic and trace metals in big game hunted in the northern part of Poland in 1987-1991. Sci Total Environ 141: 59-73. doi:10.1016/0048-9697(94)90018-3

28. Reglero M, Taggart MA, Monsalve-González L, Mateo R (2009) Heavy metal exposure in large game from a lead mining area: effects on oxidative stress and fatty acid composition in liver. Environ Pollut 157:1388-1395. doi:10.1016/j.envpol.2008.11.036

29. Crnić AP, Šuran J, Madunić HC, Božić F (2015) Cadmium concentrations in the tissues of young wild boar (Sus scrofa L.) from Moslavina and Slavonia in lowland Croatia. Vet Arh 85:323-334

30. Bilandžić N, Sedak M, Vratarić D et al (2009) Lead and cadmium in red deer and wild boar from different hunting grounds in Croatia. Sci Total Environ 407:4243-4247. doi:10.1016/j. scitotenv.2009.04.009

31. Dobrowolska A, Melosik M (2002) Mercury contents in liver and kidneys of wild boar (Sus scrofa) and red deer (Cervus elaphus). Z Jagdwiss 48:156-160. doi:10.1007/BF02192403

32. Ertl K, Kitzer R, Goessler W (2016) Elemental composition of game meat from Austria. Food Addit Contam Part B 9:120-126. doi:10.1080/19393210.2016.1151464

33. Gunn SA, Gould TC (1957) Selective accumulation of Cd115 by cortex of rat kidney. Proc Soc Exp Biol Med 96:820-823 
34. Scheuhammer AM (1987) The chronic toxicity of aluminium, cadmium, mercury and lead in birds: a review. Environ Pollut 46:263295. doi:10.1016/0269-7491(87)90173-4

35. Binkowski ŁJ, Sawicka-Kapusta K (2015) Cadmium concentrations and their implications in Mallard and Coot from fish pond areas. Chemosphere 119:620-625. doi:10.1016/j. chemosphere.2014.07.059

36. Binkowski ŁJ, Sawicka-Kapusta K (2015) Lead poisoning and its in vivo biomarkers in Mallard and Coot from hunting activity areas. Chemosphere 127:101-108. doi:10.1016/j. chemosphere.2015.01.003

37. Scheuhammer AM, Norris SL (1996) The ecotoxicology of lead shot and lead fishing weights. Ecotoxicology 5:279-295. doi:10.1007/BF00119051

38. Pain DJ (1990) Lead poisoning of waterfowl: a review. In: Matthews G (ed) IWRB Symp. Manag. Waterfowl Popul, Astrakhan, pp. 172-181

39. Aazami J, Esmaili-Sari A, Bahramifar N, Savabieasfahani M (2012) Total and organic mercury in liver, kidney and muscle of waterbirds from wetlands of the Caspian Sea, Iran. Bull Environ Contam Toxicol 89:96-101. doi:10.1007/s00128-012-0653-4

40. Zmetáková Z, Šalgovicova D (2008) Contamination of the wild animals with mercury in the Slovak Republic. In: Bezpečnost' a Kval. surovín a potravín, III. Nitra, pp 1-5

41. Binkowski $Ł J$ (2012) The effect of material preparation on the dry weight used in trace elements determination in biological samples. Fresenius Environ Bull 21:1956-1960

42. Świergosz R, Perzanowski K, Makosz U, Biłek I (1993) The incidence of heavy metals and other toxic elements in big game tissues. Sci Total Environ 134:225-231. doi:10.1016/S0048-9697(05 80022-1

43. Jarzyńska G, Falandysz J (2011) Selenium and 17 other largely essential and toxic metals in muscle and organ meats of red deer (Cervus elaphus) - consequences to human health. Environ Int 37: 882-888. doi:10.1016/j.envint.2011.02.017

44. Karimi M-HS, Hassanpour M, Pourkhabbaz A-R et al (2016) Trace element concentrations in feathers of five Anseriformes in the south of the Caspian Sea, Iran. Environ Monit Assess 188:1-7. doi:10.1007/s10661-015-5015-3

45. Sales J, Kotrba R (2013) Meat from wild boar (Sus scrofa L.): a review. Meat Sci 94:187-201. doi:10.1016/j.meatsci.2013.01.012
46. Taggart MA, Reglero MM, Camarero PR, Mateo R (2011) Should legislation regarding maximum $\mathrm{Pb}$ and $\mathrm{Cd}$ levels in human food also cover large game meat? Environ Int 37:18-25. doi:10.1016/j. envint.2010.06.007

47. Dobrowolska A, Melosik M (2008) Bullet-derived lead in tissues of the wild boar (Sus scrofa) and red deer (Cervus elaphus). Eur J Wildl Res 54:231-235. doi:10.1007/s10344-007-0134-y

48. Hunt WG, Watson RT, Oaks JL et al (2009) Lead bullet fragments in venison from rifle-killed deer: potential for human dietary exposure. PLoS One 4:e5330. doi:10.1371/journal.pone.0005330.6

49. Gremse F, Krone O, Thamm M et al (2014) Performance of leadfree versus lead-based hunting ammunition in ballistic soap. PLoS One 9:e102015. doi:10.1371/journal.pone.0102015

50. Trinogga A, Fritsch G, Hofer H, Krone O (2013) Are lead-free hunting rifle bullets as effective at killing wildlife as conventional lead bullets? A comparison based on wound size and morphology. Sci Total Environ 443:226-232

51. EFSA (2010) Scientific opinion on lead in food. EFSA J 8:1570. doi:10.2903/j.efsa.2010.1570

52. WHO (2000) Evaluation of certain food additives and contaminants. World Helath Organization, Geneva

53. BfR (2014) Safety of game meat obtained through hunting

54. EFSA (2012) Statement on the applicability of the margin of exposure approach for the safety assessment of impurities which are both genotoxic and carcinogenic in substances added to food/feed. EFSA J 10:2578. doi:10.2903/j.efsa.2012.2578

55. EFSA (2009) Cadmium in food. EFSA J 980:1-139. doi:10.2903/j. efsa.2009.980

56. Nasreddine L, Parent-Massin D (2002) Food contamination by metals and pesticides in the European Union. Should we worry? In: Toxicol. Lett. pp 29-41

57. MZiOS (1985) Zarządzenie MInistra Zdrowia i Opieku Społecznej w sprawie wykazu substancji dodatkowych dozwolonych $i$ zanieczyszczeń technicznych w środkach spożywczych i używkach oraz na ich powierzchni. pp 469-492

58. Binkowski ŁJ, Merta D, Przystupińska A et al (2016) Levels of metals in kidney, liver and muscle tissue and their relation to the occurrence of parasites in the red fox in the Lower Silesian Forest in Europe. Chemosphere 149:161-167. doi:10.1016/j. chemosphere.2016.01.099 